\title{
Analisis Faktor-Faktor yang Mempengaruhi Penyerapan Anggaran Belanja di Dinas Pekerjaan Umum dan Penataan Ruang Provinsi Riau
}

\author{
Yola Oktaliza, Muhammad Ahyaruddin, Annie Mustika Putri \\ Fakultas Ekonomi dan Bisnis, Universitas Muhammadiyah Riau, Pekanbaru, Indonesia \\ Email:yolaoktaliza@gmail.com
}

\section{A R T I C L E I N F O}

\section{Article History:}

Received: 26 April 2020

Accepted: 30 Mei 2020

Available online: 13 Juni 2020

Keywords:

penyerapan anggaran, kualitas sumber daya manusia, regulasi, perencanaan anggaran, komitmen manajemen

\begin{abstract}
A B S T R A C T
Untuk mewujudkan penyerapan anggaran belanja yang baik, perlu diperhatikan realisasi anggaran dengan target anggaran yang telah ditetapkan. Apabila realisasi anggarannya masih sangat jauh dari target yang telah ditetapkan pada tahun sebelumnya, maka hal tersebut mengindikasikan bahwa telah terjadi kendala dalam proses penyerapan anggaran. Penelitian ini dilakukan dengan tujuan untuk mengetahui pengaruh dan menganalisis faktor-faktor yang mempengaruhi penyerapan anggaran belanja di dinas Pekerjaan Umum dan Penataan Ruang Provinsi Riau. Jenis penelitian adalah penelitian kuantitatif yang bersifat kausal dengan metode analisis regresi berganda. Sampel yang digunakan adalah 111 Pegawai Negeri Sipil yang bekerja di Dinas Pekerjaan Umum dan Penataan Ruang Provinsi Riau. Pengumpulan data menggunakan kuisioner. Hasil penelitian ini menemukan bahwa faktor kualitas sumber daya manusia, regulasi, perencanaan anggaran dan komitmen manajemen berpengaruh positif terhadap penyerapan anggaran belanja. Hal ini memberikan implikasi bahwa pemerintah daerah harus bisa memaksimalkan penyerapan anggarannya dengan meningkatkan kualitas perencanaan penyusunan anggaran, meningkatkan sumber daya pegawai dan merekrut pegawai sesuai spesialisasinya. Selain itu diharapkan kepada pemerintah untuk tidak selalu memperbarui regulasi karena regulasi yang selalu berubah-ubah menyebabkan pegawai negeri sipil kesulitan untuk melakukan program kerjanya.
\end{abstract}

\section{Pendahuluan}

Untuk mempercepat proses pelaksanaan program pembangunan pemerintah, tanggal 16 januari 2014 yang lalu presiden Joko Widodo menerbitkan Instruksi Presiden Republik Indonesia Nomor 1 Tahun 2015 Tentang Percepatan Pelaksanaan Pengadaan Barang Dan Jasa Pemerintah . Intruksi ini ditujukan kepada Para menteri Kabinet Kerja, Kepala Kepolisian Negara Republik Indonesia, Jaksa Agung, Panglima TNI, Sekretaris Kabinet, Para Kepala Lembaga Pemerintah Non Kementerian (LPNK), para Pimpinan Kesekretariatan
Lembaga Negara, para Gubernur dan Bupati/Walikota. Dalam instruksinya tersebut, Presiden menekankan untuk mengambil langkah-langkah yang tepat dalam melaksanakan pengadaan barang dan jasa Pemerintah. Langkah-langkah tersebut adalah menyelesaikan Rencana Umum Pengadaan Barang/Jasa Pemerintah tahun anggaran berikutnya sebelum berakhirnya tahun anggaran berjalan dan dilakukan secara transparan, cermat, dan akuntabel. Presiden menekankan betapa pentingnya proses penyerapan anggaran yang maksimal dan sesuai dengan rencana kerja 
yang telah direncanakan pada tahun sebelumnya. Akan tetapi, walaupun Inpres tersebut telah diterbitkan, masih saja banyak laporan yang menyatakan bahwa proses penyerapan anggaran masih terlambat.

Penyerapan anggaran yang baik dapat dilihat dari tingkat pelaksanaan realisasi fisik dan realisasi anggaran yang terjadwal sesuai dengan rencana kerja selama satu periode tahun anggaran. Pada pertengahan tahun seharusnya realisasi penyerapan anggaran sudah mencapai $50 \%$ dan diakhir tahun dapat dimaksimalkan menjadi $100 \%$. Namun saat ini fenomena yang kerap kali terjadi adalah lambatnya proses penyerapan anggaran, dimana penyerapan anggaran rendah pada awal tahun dan cenderung menumpuk di akhir tahun (Rifai, 2011).

Menteri Keuangan Sri Mulyani Indrawati mengatakan ada dua kementerian yang realisasi penyerapan anggarannya masih rendah dalam kurun waktu 6 bulan ini, yakni Kementerian Pekerjaan Umum dan Penataan Ruang (PUPR) yang baru terealisasi 27,07\% atau Rp 29,07 triliun dan Kementerian Perhubungan sebesar 22,78\% atau Rp 10,98 triliun (www.finance.detik.com, 2018). Hal itu juga berdampak pada kinerja dinas PUPR Provinsi Riau. Berdasarkan data yang bersumber dari website www.monev.riau.go.id, tingkat penyerapan dana APBD oleh Dinas PUPR Provinsi Riau sangat rendah. Sampai bulan oktober 2018, dinas PUPR Provinsi Riau hanya mampu menyerap $27,13 \%$ dari target awal sebesar $80,80 \%$. Sementara penyerapan untuk realisasi fisik hanya sebesar $41,50 \%$ dari target awal sebesar $49,21 \%$. Hal ini tentu saja menimbulkan banyak pertanyaan di masyarakat. Apakah dinas PUPR tidak dapat melaksanakan kegiatan yang telah direncanakan atau karena terjadi efisiensi anggaran. Penyerapan anggaran yang tinggi tanpa adanya output serta outcome yang optimal justru menunjukkan kinerja yang kurang baik.

Bersadarkan permasalahan tersebut, penelitian ini bertujuan untuk mengidentifikasi factor-faktor yang mempengaruhi penyerapan anggaran pemerintah khususnya di dinas PUPR Provinsi Riau. Beberapa faktor telah diidentifikasi adalah kualitas sumber daya manusia, regulasi, perencanaan anggaran dan komitmen manajemen (Dwiyana, 2017; Rerung et al, 2016; Henry, 2017; Juliani dan Sholihin,
2014; Herriyanto, 2012). Kualitas sumber daya manusia adalah kemampuan pegawai negeri sipil dalam melaksanakan seluruh tugastugasnya. Salah satu penelitian yang dilakukan oleh Dwiyana (2017) menjelaskan bahwa kualitas Sumber Daya Manusia yang baik akan menyerap anggarannya dengan baik. Namun, Rifai (2011) dan Rerung et al (2016) mengungkapkan bahwa dalam konsep teori stewardship, Sumber Daya Manusia yang tidak memiliki sertifikat yang memadai, tidak pernah mengikuti pelatihan, dan bahkan sering terjadi perangkapan tugas menyebabkan proses penyerapan anggaran menjadi tidak baik.

Di sisi lain, factor regulasi menjadi penting dalam proses penyerapan anggaran. Regulasi terkait dengan tata aturan yang sengaja dibuat untuk dijadikan pedoman dalam melakukan suatu kegiatan dan memiliki kekuatan hukum. Henry (2017) mengungkapkan bahwa regulasi berpengaruh signifikan terhadap proses penyerapan anggaran. Selanjutnya, factor perencanaan anggaran dan komitmen manajemen juga berperan penting dalam proses penyerapan anggaran. Herriyanto (2012) menjelaskan bahwa perencanaan anggaran berpengaruh sebesar $42,91 \%$ terhadap proses penyerapan anggaran. Sedangkan komitmen manajemen adalah kegiatan melakukan dan mempertahankan perilaku yang membantu bawahan untuk mencapai suatu tujuan. Rerung (2016) menyimpulkan bahwa komitmen manajemen dapat mempengaruhi penyerapan anggaran terkait dalam proses penyediaan barang dan jasa.

Berdasarkan penjelasan tersebut, penelitian ini secara khusus ingin melihat apakah kualitas SDM, regulasi, perencanaan anggaran, dan komitmen manajemen berpengaruh terhadap proses penyerapan anggaran di dinas PUPR Provinsi Riau. Hasil penelitian ini diharapkan dapat memberikan kontribusi kepada pemerintah sebagai bahan masukan dan pertimbangan untuk penentuan kebijakan daerah dalam upaya meningkatkan efisiensi dan efektifitas anggaran. 


\section{Tinjauan Pustaka dan Pengembangan Hipotesis}

Teori Stewardship

Menurut Donaldson et al (1991), teori stewardship adalah teori yang menggambarkan situasi dimana para manajer tidak termotivasi oleh kepentingan-kepentingan individu melainkan lebih fokus dengan tujuan organisasi. Teori ini mempunyai dasar psikologi dan sosiologi yang telah dirancang dimana para eksekutif sebagai steward termotivasi untuk bertindak sesuai keinginan prinsipal, selain itu perilaku steward tidak akan meninggalkan organisasinya sebab steward berusaha mencapai sasaran organisasinya. Berdasarkan teori stewardship, prinsipal mengharapkan tanggung jawab bersama sesuai dengan kontribusi steward.

Dalam teori stewardship, terdapat suatu model yang didasarkan pada pelayan yang memiliki perilaku dimana dia dapat dibentuk agar selalu dapat diajak bekerjasama dalam organisasi, memiliki perilaku kolektif atau berkelompok dengan utilitas tinggi daripada individunya dan selalu bersedia untuk melayani, model ini disebut dengan model of man. Pada teori stewardship terdapat suatu pilihan antara perilaku self serving dan pro-organisational, perilaku pelayan tidak akan dipisahkan dari kepentingan organisasi adalah bahwa perilaku eksekutif disejajarkan dengan kepentingan principal dimana para steward berada. Steward akan menggantikan atau mengalihkan self serving untuk berperilaku kooperatif (Anton, 2010). Kesimpulannya, meskipun kepentingan antara steward dan principal berbeda, steward tetap akan menjunjung tinggi nilai-nilai kebersamaan.

Teori ini dapat dihubungkan dengan sektor publik karena pihak steward bertindak berdasarkan keinginan Principal. Maksudnya pihak pemerintah akan melakukan tugasnya sesuai dengan keinginan dan kepentingan rakyat. Teori tersebut mengasumsikan adanya hubungan yang kuat antara kepuasan dan kesuksesan organisasi. Kesuksesan organisasi menggambarkan output yang maksimal ini akan memberikan tingkat kepuasan yang maksimal terhadap pihak principal. Dengan begitu principal akan menilai kinerja yang dilakukan oleh Steward sangat baik.

\section{Pengaruh Kualitas Sumber Daya Manusia terhadap Penyerapan Anggaran Belanja}

Kinerja organisasi akan terlihat buruk jika organisasi tersebut tidak mampu menyerap anggarannya secara optimal. Baiknya kinerja sebuah organisasi tidak terlepas dari peranan Sumber Daya Manusianya. Hal ini dapat terlihat dari manusianya yang disebut juga sebagai Pegawai Negeri Sipil, yang memanfaatkan kemampuan fisik dan psikisnya secara optimal demi mancapai tujuan organisasinya (Rerung, 2016). Untuk mencapai daya guna dan hasil guna yang sebesar-besarnya, pemerintah mengadakan pengaturan, penyelenggaraan pendidikan dan pelatihan jabatan Pegawai Negeri Sipil yang bertujuan untuk meningkatkan pengabdian, mutu, keahlian, kemampuan dan keterampilan (UU RI No.43 tahun 1999 tentang Perubahan atas UndangUndang Nomor 8 Tahun 1974 tentang PokokPokok Kepegawaian).

Penelitian terdahulu yang dilakukan oleh Zarinah (2016) menjelaskan bahwa variabel Kualitas Sumber Daya Manusia merupakan faktor yang dapat mempengaruhi proses penyerapan anggaran. Ia juga menyatakan bahwa semakin tinggi kualitas sumber daya manusia maka akan semakin baik pula tingkat penyerapan anggaran. Hal ini sejalan dengan penelitian yang dilakukan oleh Herriyanto (2012), Kirnanda (2016), yang menunjukkan bahwa Sumber Daya Manusia merupakan faktor yang berpengaruh terhadap proses penyerapan anggaran. Berdasarkan hasil penelitian sebelumnya, maka hipotesis yang pertama di ajukan ialah :

H1: Kualitas Sumber Daya Manusia berpengaruh positif terhadap penyerapan Anggaran Belanja

\section{Pengaruh Regulasi terhadap Penyerapan Anggaran Belanja}

Regulasi merupakan sebuah tata aturan yang sengaja dibuat untuk dijadikan pedoman dalam melakukan suatu kegiatan dan memiliki kekuatan hukum. Salah satu hal yang menjadi penghambat penyerapan anggaran adalah regulasi. Menurut Rifai (2016) ada dua hal yang sering menjadi hambatan yaitu masalah perijinan terhadap perjanjian kontrak tahun jamak dan regulasi pengadaan tanah dan bangunan. Pada perjanjian kontrak tahun jamak, 
masalahnya terletak pada perijinan yang panjang yaitu membutuhkan ijin Menteri Keuangan. Untuk pengadaan tanah di isyaratkan untuk melakukan clearance oleh Kementrian PAN dan RB, BPKP dan Kementrian PU.

Penelitian terdahulu yang dikembangkan oleh Sembiring (2017) menjelaskan bahwa Regulasi berpengaruh signifikan terhadap proses penyerapan anggaran belanja. Hal ini sejalan dengan penelitian Arif (2011) yang dilakukan dengan teknik wawancara. Ia menyatakan bahwa Regulasi mempengaruhi minimnya serapan anggaran di Kabupaten Rokan Hulu. Namun berbeda dengan penelitian Rifai (2016) yang menyatakan bahwa regulasi bukanlah faktor yang mempengaruhi proses penyerapan APBD. Berdasarkan hasil penelitian sebelumnya, maka hipotesis kedua yang diajukan adalah:

H2: Regulasi berpengaruh positif terhadap Penyerapan Anggaran Belanja

\section{Pengaruh Perencanaan Anggaran terhadap Penyerapan Anggaran Belanja}

Perencanaan merupakan rencana tertulis yang menjelaskan kemana arah organisasi (tujuan), bagaimana cara untuk mencapainya (strategi), dan hasil apa yang seharusnya diharapkan/target kinerja (Merchant \& Stede, 2016). Perencanaan anggaran menjadi salah satu faktor yang mempengaruhi proses penyerapan anggaran karena perencanaan anggaran memberikan kontribusi besar terhadap penyerapan anggaran, sehingga semakin baik perencanaan anggaran maka akan semakin baik penyerapan anggaran.

Penelitian terdahulu yang ditulis oleh Gagola et al (2016) menyimpulkan bahwa penyerapan anggaran dipengaruhi oleh perencanaan anggaran. Sejalan dengan penelitian Dwiyana (2017) yang menyebutkan bahwa variabel perencanaan anggaran berpengaruh positif signifikan. Menurutnya penyusunan perencanaan anggaran sudah menggunakan pendekatan anggaran berbasis kinerja, dengan instrumen capaian kinerja, indikator kinerja, analisis standar belanja, standar satuan harga dan standar pelayanan minimal. Berdasarkan hasil penelitian sebelumnya, maka hipotesis ketiga yang diajukan adalah:
H3: Perencanaan Anggaran berpengaruh positif terhadap Penyerapan Anggaran

\section{Pengaruh Komitmen Manajemen terhadap Penyerapan Anggaran Belanja}

Menurut Cooper (2015), komitmen manajemen adalah kegiatan melakukan dan mempertahankan perilaku yang membantu bawahan untuk mencapai suatu tujuan. Suksesnya manajemen sebuah organisasi tidak terlepas dari komitmen manajemen, terutama komitmen manajemen puncak. Para manajer sering diragukan oleh karyawannya jika ia tidak mampu menjaga dan menghidupkan sistem organisasinya.

Menurut Rerung et al (2016), komitmen manajemen berpengaruh terhadap penyerapan anggaran yang terkait dengan pengadaan barang dan jasa. Begitu pula dengan penelitian Juliani \& Sholihin (2014) yang mengungkapkan bahwa komitmen manajemen berpengaruh terhadap penyerapan anggaran. Menurutnya komitmen manajemen merupakan peran kepala SKPD selaku pengguna anggaran dengan berbagai upaya untuk mencapai target penyerapan anggaran yang maksimal. Jadi, jika didalam suatu organisasi memiliki tingkat komitmen manajemen yang baik, maka hal itu akan berdampak baik dalam proses penyerapan anggaran. Berdasarkan hasil penelitian sebelumnya maka hipotesis ketiga yang diajukan adalah:

H4: Komitmen Manajemen berpengaruh positif terhadap penyerapan anggaran belanja.

\section{Metode Penelitian}

Penelitian ini merupakan jenis penelitian kuantitatif yang bersifat kausal. Penelitian ini bertujuan untuk mengetahui dan menganalisis pengaruh tingkat kualitas Sumber Daya Manusia, Regulasi, Perencanaan Anggaran dan Komitmen Manajemen terhadap proses penyerapan Anggaran Belanja. Teknik analisis data menggunakan regresi linier berganda. Sampel penelitian ini adalah sebanyak 111 Pegawai Negeri Sipil yang bekerja di Dinas PUPR Provinsi Riau dengan kriteria yaitu orang yang menduduki jabatan dalam bidang yang berkaitan dengan pengelola anggaran dan pengadaan barang/jasa.

Variabel penyerapan anggaran dalam penelitian ini diukur menggunakan kuisioner 
yang diadopsi dari penelitian Kirnanda (2016) dengan indikator perbandingan antara pagu anggaran belanja dengan realisasi belanja. Kualitas sumber daya manusia diukur menggunakan kuisioner penelitian Dwiyana (2017) dengan indikator rangkap tugas/jabatan, mutasi pegawai penatausahaan Keuangan. Regulasi diukur menggunakan kuisioner penelitian Sembiring (2017) dengan indikator perubahan peraturan disesuaikan dengan kebutuhan publik, sosialisasi peraturan yang baru, peraturan / kebijakan tepat sasaran, Peraturan / kebijakan tidak membingungkan publik. Perencanaan anggaran diukur menggunakan kuisioner dari penelitian Dwiyana (2017) dengan indikator kesesuaian dengan kebutuhan, sesuai dengan tugas pokok dan fungsi SKPD, pencapaian sasaran rencana kerja/rencana strategi. Komitmen manajemen diukur menggunakan kuisioner dari penelitian Juliani \& Sholihin (2014) dengan indikator komitmen mencapai target penyerapan anggaran, komitmen pimpinan terhadap dukungan pelatihan, pemberdayaan terhadap pegawai dalam pelaksanaan pengadaan barang/jasa, penghargaan atas kinerja pegawai dan kemampuan memberikan solusi terhadap permasalahan.

\section{Hasil Penelitian dan Pembahasan}

Penelitian ini merupakan penelitian survei dalam bentuk pengiriman kuisioner kepada responden. Sebanyak 111 responden yang diteliti terdiri dari 68 pria dan 43 wanita dengan usia rata-rata berkisar antara 36-50 tahun sebanyak 63 orang atau 56,8\%. Rata-rata responden yang diteliti memiliki kompetensi yang memadai terlihat dari tingkat pendidikan yang rata-rata level sarjana yaitu 68 orang
61,3\%. Dan sudah memiliki pengalaman kerja yang mumpuni yaitu 5-10 tahun sebanyak 56 orang atau 50,5\%. Gambaran detil responden bisa dilihat pada Tabel 1 berikut:

Tabel 1: Profil Responden $(\mathrm{N}=111)$

\begin{tabular}{|c|c|c|c|}
\hline \multicolumn{2}{|c|}{ Karakteristik Responden } & \multirow{2}{*}{$\frac{\text { Jumlah }}{68}$} & \multirow{2}{*}{$\frac{\%}{61,3 \%}$} \\
\hline Jenis & Pria & & \\
\hline Kelamin: & Wanita & 43 & $38,7 \%$ \\
\hline \multirow{4}{*}{ Umur: } & $<25$ & 1 & $0,9 \%$ \\
\hline & $26-35$ & 34 & $30,6 \%$ \\
\hline & $36-50$ & 63 & $56,8 \%$ \\
\hline & $>50$ & 13 & $11,7 \%$ \\
\hline Tingkat & SMA & 6 & $5,4 \%$ \\
\hline \multirow[t]{4}{*}{ Pendidikan: } & : Diploma & 23 & $20,7 \%$ \\
\hline & Sarjana & 68 & $61,3 \%$ \\
\hline & Master & 12 & $10,8 \%$ \\
\hline & Doktor & 2 & $1,8 \%$ \\
\hline Lama & $<2$ tahun & 4 & $3,6 \%$ \\
\hline \multirow[t]{3}{*}{ Menjabat: } & $2-5$ tahun & 35 & $31,5 \%$ \\
\hline & 5-10 tahun & 56 & $50,5 \%$ \\
\hline & 10-15 tahun & 16 & $14,4 \%$ \\
\hline \multicolumn{2}{|c|}{ Pengalaman Pernah } & 44 & $39,6 \%$ \\
\hline \multirow[t]{3}{*}{ Diklat: } & Jarang & 3 & $2,7 \%$ \\
\hline & Sering & 63 & $56,8 \%$ \\
\hline & Sangat Sering & 1 & $0,9 \%$ \\
\hline
\end{tabular}

Sebelum pengujian hipotesis dilakukan, beberapa syarat harus dipenuhi terlebih dahulu, yaitu uji validitas dan reliabilitas. Hasil pengujian validitas menggunakan pearson correlation dan reliabilitas menggunakan cronbach Alpha telah memenuhi standar yang ditetapkan. Kemudian peneliti juga melakukan uji asumsi klasik berupa uji normalitas, heteroskedastisitas dan multikolinieritas. Hasil pengujian tersebut semuanya telah memenuhi syarat sehingga bisa dilanjutkan untuk analisis regresi linier berganda. Hasil pengujian hipotesis melalui uji $\mathrm{t}$ untuk mengetahui besarnya pengaruh masing-masing variabel independen secara individual terhadap variabel dependen dapat dilihat pada table berikut:

\section{Tabel 2: Hasil Pengujian Hipotesis}

\begin{tabular}{|c|c|c|c|c|c|}
\hline \multirow[b]{2}{*}{ Model } & \multicolumn{2}{|c|}{ Unstandardized Coefficients } & \multirow{2}{*}{$\begin{array}{c}\text { Standardized } \\
\text { Coefficients } \\
\text { Beta }\end{array}$} & \multirow[b]{2}{*}{$\mathrm{t}$} & \multirow[b]{2}{*}{ Sig. } \\
\hline & $\mathrm{B}$ & Std. Error & & & \\
\hline (Constant) & .107 & 2.136 & & .050 & .960 \\
\hline Kualitas_SDM & .138 & .031 & .350 & 4.478 & .000 \\
\hline Regulasi & .319 & .057 & .414 & 5.623 & .000 \\
\hline Perencanaan_Anggaaran & .087 & .036 & .189 & 2.431 & .017 \\
\hline Komitmen_Manajemen & .141 & .056 & .183 & 2.515 & .013 \\
\hline
\end{tabular}




\section{Pengaruh Kualitas Sumber Daya Manusia Terhadap Penyerapan Anggaran Belanja}

Berdasarkan hasil uji hipotesis maka dapat diketahui bahwa hasil pengujian dari variabel kualitas sumber daya manusia mempunyai nilai signifikansi 0,000 lebih kecil dari 0,05. Maka hal ini menunjukkan bahwa H1 diterima. Sehingga dapat disimpulkan bahwa variabel kualitas sumber daya manusia berpengaruh terhadap penyerapan anggaran belanja. Pengaruh positif ini menunjukkan bahwa semakin baik kualitas sumber daya manusia yang dimiliki maka akan mempermudah dalam melaksanakan tugas dan tanggung jawabnya. Sejalan dengan proses penyerapan anggaran belanja dimana semakin meningkatnya kualitas sumber daya manusia tersebut maka akan semakin meningkat pula proses penyerapan anggaran.

Sumber daya manusia yang berkualitas tinggi akan menjadi keunggulan tersendiri dalam sebuah organisasi sekaligus sebagai pembangun citra yang baik agar timbul rasa kepercayaan di masyarakat. Hal ini sejalan dengan teori stewardship dimana dinas Pekerjaan Umum dan Penataan Ruang provinsi Riau sebagai pihak steward yang berfungsi sebagai pengelola sumber daya masyarakat (pihak principal). Semakin baik kualitas sumber daya manusia yang dimiliki Dinas PUPR (Steward) dalam melaksanakan tugas dari masyarakat (Principal), maka serapan anggaran akan menjadi lebih baik karena sumber daya manusianya sudah paham dengan tugas-tugas yang menjadi tanggung jawabnya.

Pendapat tersebut sejalan dengan penelitian terdahulu yang telah dilakukan oleh Kirnanda (2016), zarinah (2016) dan Dwiyana (2017) yang mengatakan bahwa kualitas sumber daya manusia berpengaruh positif terhadap realisasi penyerapan anggaran belanja. Zarinah (2016) mengatakan bahwa faktor kunci keberhasilan dalam pengelolaan anggaran adalah staf yang berpengalaman dan mempunyai motivasi.

Variabel kualitas sumber daya manusia berpengaruh positif terhadap penyerapan anggaran karena rata-rata pengelola keuangan dan seluruh pegawai pernah mengikuti kursus/diklat/bimbingan yang berkaitan dengan pengelolaan keuangan (lihat tabel 4.8). Dan seluruh responden pengelola keuangan berpendidikan diploma dan S1 dengan program pendidikan ilmu ekonomi. Untuk responden lainnya berpendidikan mulai dari SMA hinga S3 dengan program studi teknik sipil. Dan ratarata masa kerja seluruh responden berada diatas 5 tahun yang berarti telah berpengalaman dan berkompetensi. Kualitas sumber daya manusia merupakan tuntutan yang harus memiliki tingkat pengetahuan, kemampuan dan kemauan yang sangat baik sehingga dapat ditunjukkan dengan hasil kinerja yang efektif dan efisien.

\section{Pengaruh Regulasi Terhadap Penyerapan Anggaran Belanja}

Berdasarkan hasil uji hipotesis maka dapat diketahui bahwa hasil pengujian dari variabel regulasi mempunyai nilai signifikansi 0,000 lebih kecil dari 0,05 dengan nilai beta sebesar 0,319 yang memiliki arti bahwa varibel ini merupakan variabel yang paling besar dalam mempengaruhi proses penyerapan anggaran. Maka hal ini menunjukkan bahwa $\mathrm{H} 2$ diterima. Sehingga dapat disimpulkan bahwa variabel regulasi berpengaruh terhadap penyerapan anggaran belanja. Pengaruh positif ini menunjukkan bahwa semakin jelas regulasi yang diterbitkan maka hal ini akan mempermudah pegawai dalam melaksanakan tugas dan tanggung jawabnya. Sejalan dengan proses penyerapan anggaran belanja dimana semakin jelasnya regulasi tersebut maka akan semakin meningkat pula proses penyerapan anggaran.

Regulasi merupakan serangkaian tata aturan yang sengaja dibuat untuk dijadikan pedoman dalam melakukan suatu kegiatan dan memiliki kekuatan hukum. Dalam UU Nomor 12 tentang Pembentukan Peraturan PerundangUndangan (2011) dikatakan bahwa peraturan perundang-undangan yang diatur dalam undang-undang ini meliputi undang-undang dan peraturan-peraturan dibawahnya. Peraturan menteri, petunjuk teknis, petunjuk pelaksanaan ataupun Surat Edaran (SE) adalah dianggap sebagai jenis peraturan perundang-undangan. Artinya regulasi tersebut dapat berubah-ubah sesuai keadaan asalkan tidak melanggar undang-undang diatasnya.

Berdasarkan teori stewardship, jika regulasi yang dikeluarkan jelas, maka pelaksanaan pekerjaan akan memudahkan si pegawai (steward) dalam melaksanakan 
program dan kegiatan yang ada disatuan kerja sehingga diharapkan serapan anggaran lebih cepat dilakukan.jika regulasi sering berubahubah, maka akan menimbulkan kebimbangan bagi pegawai (Steward) dalam melaksanakan program kerja yang diinginkan oleh masyarakat (principal).

Hasil penelitian ini sejalan dengan penelitian yang dilakukan oleh Sembiring (2017) dan Arif (2012) yang mengatakan bahwa regulasi berpengaruh positif signifikan terhadap proses realisasi anggaran.

Pengaruh positif ini juga sesuai dengan keadaan regulasi didalam Dinas Pekerjaan Umum dan Penataan Ruang Provinsi Riau. Regulasi tersebut terdiri dari undang-undang, peraturan pemerintah pengganti undang-undang peraturan pemerintah, peraturan presiden, keputusan presiden, instruksi presiden, peraturan menteri, keputusan menteri, instruksi menteri, surat edaran menteri, surat edaran sekretaris jenderal, surat edaran direktur jenderal, surat edaran inspektur jenderal, surat edaran kepala badan, MoU dan peraturan daerah (Birohukum.pu.go.id). Hal ini menjelaskan bahwa semua regulasi yang tersedia didalam dinas PUPR Provinsi Riau sudah sangat jelas dan teratur sehingga jika para Pegawai Negeri Sipil mengikuti seluruh regulasi tersebut dengan tertib maka mereka akan lebih mudah dalam melaksanakan program kerja yang telah direncanakan.

\section{Pengaruh Perencanaan Anggaran Terhadap Penyerapan Anggaran Belanja}

Berdasarkan hasil uji hipotesis maka dapat diketahui bahwa hasil pengujian dari variabel perencanaan anggaran mempunyai nilai signifikansi 0,017 lebih kecil dari 0,05. Maka hal ini menunjukkan bahwa H3 diterima. Sehingga dapat disimpulkan bahwa variabel perencanaan anggaran berpengaruh terhadap penyerapan anggaran belanja. Pengaruh positif ini menunjukkan bahwa semakin baik perencanaan anggaran yang disusun maka akan semakin baik tingkat penyerapan anggarannya. Begitu pula sebaliknya, jika perencanaan anggaran yang disusun tidak baik, maka buruk pula tingkat penyerapan anggarannya.

Didalam Instruksi Presiden Republik Indonesia Nomor 1 Tahun 2015 Tentang Percepatan Pelaksanaan Pengadaan Barang dan
Jasa Pemerintah, dikatakan bahwa perencanaan tahun anggaran berikutnya harus diselesaikan sebelum berakhirnya tahun anggaran berjalan dan harus dilakukan secara cermat, transparan dan akuntabel. Proses perencanaan kegiatan dalam penganggaran merupakan proses yang paling utama. Sejak beberapa bulan sebelum tahun anggaran dimulai, proses perencanaan anggaran sudah berjalan. Setiap bidang ataupun UPT dalam Dinas Pekerjaan Umum dan Penataan Ruang Provinsi Riau harus menyusun kerangka acuan kerja beserta rencana anggaran biayanya.

Berdasarkan kerangka teori stewardship, pihak principal dan steward memiliki tujuan yang selaras dengan tujuan organisasi demi mencapai kesuksesan organisasi. Masyarakat atau pemberi amanah (principal) memiliki hak dan kewenangan untuk meminta dinas PUPR atau penerima amanah (steward) untuk mempertanggungjawabkan, menyajikan, melaporkan serta mengungkapkan segala aktivitas dan kegiatan yang menjadi tanggungjawabnya termasuk juga dalam hal ini pihak principal harus melaporkan perencanaan program yang telah mereka buat.

Hasil penelitian ini mendukung penelitian yang dilakukan oleh Juliani \& Sholihin (2014), Rerung (2016), Sudastri (2016) yang mengatakan bahwa perencanaan anggaran merupakan faktor yang penting dalam proses penyerapan anggaran. Aspek perencanaan yang tidak matang dalam penentuan anggaran yang akan disajikan akan berdampak pada gagalnya program kerja yang akan dilaksanakan.

Proses perencanaan di Dinas PUPR Provinsi Riau diawali dengan pembuatan Rencana Pembangunan Jangka Panjang Daerah (RPJPD). RJPD digunakan sebagai acuan untuk membuat penyusunan Rencana Pembangunan Jangka Menengah Daerah (RPJMD). Setelah RPJMD ditetapkan, maka pemerintah menyusun Rencana Kerja Pemerintah Daerah (RKPD) untuk jangka waktu satu tahun. Kepala daerah berdasarkan RKPD menyusun rancangan Kebijakan Umum APBD (KUA). Setelah KUA disepakati, maka kepala daerah menerbitkan Rencana Kerja dan Anggaran (RKA) SKPD berdasarkan nota kesepakatan. Perencanaan yang jelas dan terencana akan menguatkan proses penyerapan anggaran. 


\section{Pengaruh Komitmen Manajemen terhadap Penyerapan Anggaran Belanja}

Berdasarkan hasil uji hipotesis maka dapat diketahui bahwa hasil pengujian dari variabel komitmen manajemen mempunyai nilai signifikansi 0,013 lebih kecil dari 0,05. Maka hal ini menunjukkan bahwa $\mathrm{H} 4$ diterima. Sehingga dapat disimpulkan bahwa variabel komitmen manajemen berpengaruh terhadap penyerapan anggaran belanja. Pengaruh positif ini menunjukkan bahwa semakin baik komitmen manajemen, maka akan semakin baik pula tingkat penyerapan anggarannya. Begitu pula sebaliknya, jika pihak manajemen tidak memiliki komitmen yang baik dan tidak memberikan dukungan secara nyata kepada para pegawainya, maka tingkat penyerapan anggarannya akan rendah.

Dukungan dari kepala organisasi sangat diperlukan untuk perbaikan dalam pelaksanaan anggaran terkait penyediaan barang dan jasa khususnya belanja modal pada instansi yang dipimpinnya (Rerung, 2016). Komitmen yang tinggi dari kepala organisasi sangat mempengaruhi penyerapan anggaran belanja. Berdasarkan teori stewardship, komitmen manajemen merupakan peran dari kepala sebuah organisasi (steward) selaku pengguna anggaran yang berupaya menerapkan berbagai macam strategi untuk mencapai target penyerapan anggaran yang maksimal. Dengan komitmen manajemen yang bersungguhsungguh terhadap pemberian kualitas layanan, maka akan tercipta keselarasan terhadap kepuasan antara masyarakat atau pemberi amanah (principal) dengan pemerintah (steward).

Beberapa bentuk komitmen manajemen yang telah dilaksanakan oleh kepala dinas PUPR Provinsi Riau yaitu selalu memberikan kesempatan kepada karyawan untuk membuat suatu rencana pembangunan, hal ini sangat bermanfaat untuk mengasah kemampuan PNS dalam bekerja. Selain itu kepala Dinas juga selalu mengevaluasi hasil kerja yang telah dilaksanakan, apabila terjadi kendala maka kepala Dinas siap memberikan solusi dalam permasalahan yang tengah dihadapi. Jika kepala dinas selalu menerapkan komitmen seperti ini secara terus menerus, maka seluruh kendala yang dihadapi ketika melakukan kegiatan akan mudah dihilangkan sehingga proses penyerapan anggaran jauh lebih cepat terlaksana.

Hasil penelitian ini mendukung penelitian yang dilakukan oleh Gagola et al (2016), Juliani \& Sholihin (2014), Rerung (2016) yang mengatakan bahwa variabel komitmen manajemen merupakan faktor yang mempengaruhi proses penyerapan anggaran. Menurut Rerung (2016) komitmen manajemen merupakan faktor pendorong untuk memotivasi karyawan agar berupaya meningkatkan kualitas proses yang berkesinambungan dan manajemen harus terlibat langsung dalam mempertahankan kinerja karyawan untuk mencapai tujuan.

\section{KESIMPULAN}

Hasil pengujian menemukan bukti bahwa kualitas sumber daya manusia, regulasi, perencanaan anggaran, dan komitmen manajemen berpengaruh signifikan terhadap penyerapan anggaran belanja. Sumber daya manusia yang berkualitas tinggi akan menjadi keunggulan tersendiri dalam sebuah organisasi sekaligus sebagai pembangun citra yang baik agar timbul rasa kepercayaan di masyarakat sehingga proses penyerapan anggaran bisa berjalan dengan baik. Selanjutnya kejelasan regulasi yang diterbitkan oleh pemerintah akan mempermudah pegawai dalam melaksanakan tugas dan tanggung jawabnya. Hal ini berarti bahwa semakin jelas regulasi akan membuat proses penyerapan anggaran belanja semakin baik. Terakhir, perencanaan anggaran yang baik dan komitmen manajemen yang tinggi akan memiliki implikasi terhadap penyerapan anggaran belanja yang semakin meningkat.

Penelitian ini memiliki beberapa keterbatasan. Pertama, penelitian ini hanya dilakukan pada satu dinas yakni Dinas Pekerjaan Umum dan Penataan Ruang Provinsi Riau, sehingga hasil penelitian belum tentu dapat digeneralisasi ke seluruh organisasi yang ada. Kedua, data yang digunakan hanya data primer yang bersumber dari kuisioner sehingga masih ada keraguan apakah responden yang dituju benar-benar mengisi kuisioner tersebut dengan baik atau tidak.

Penelitian ini memberikan implikasi praktis bagi pemerintah daerah khususnya Dinas Pekerjaan Umum dan Penataan Ruang agar dapat memaksimalkan penyerapan anggarannya dengan meningkatkan kualitas 
perencanaan penyusunan anggaran, meningkatkan sumber daya pegawai dan merekrut pegawai sesuai spesialisasinya. Selain itu diharapkan kepada pemerintah untuk tidak selalu memperbarui regulasi karena regulasi yang selalu berubah-ubah menyebabkan pegawai negeri sipil kesulitan untuk melakukan program kerjanya, dan hal itupun akan memperlambat proses penyerapan anggaran. Selalu meningkatkan komitmen manajemen dengan cara melakukan monitoring dan evaluasi terhadap pencapaian kinerja pegawai dan selalu mendukung pelatihan teknis para pegawai negeri sipil.

\section{DAFTAR PUSTAKA}

Anton, F. X. (2010). Menuju Teori Stewardship Manajemen.

Arif, E. (2012). Identifikasi Faktor-Faktor Penyebab Minimnya Penyerapan Anggaran Pendapatan dan Belanja Daerah (APBD) Kabupaten/Kota di Provinsi Riau Tahun 2011, 19(2), 41-62.

Birohukum.pu.go.id. (n.d.). produk hukum kementrian pekerjaan umum dan penataan ruang.

Cooper, D. (2015). Exploratory Analyses of the Effects of Managerial Support and Feedback Exploratory Analyses of the Effects of Managerial Support and Feedback Consequences on Behavioral Safety Maintenance, (November). https://doi.org/10.1300/J075v26n03

Donaldson, L., Davis, J. H., Argyris, C., Chandler, A., Etzioni, A., Hage, J., ... Whetten, D. (1991). Stewardship Theory or Agency Theory: CEO Governance and Shareholder Returns. Australian Journal of Management, 16, 49-64.

Dwiyana, N. (2017). Faktor-Faktor Yang Mempengaruhi Penyerapan Anggaran Satuan Kerja Perangkat Daerah Pemerintah Kota Medan Dengan Monitoring Dan Evaluasi Sebagai Variabel Moderating. Universitas Sumatera Utara. Retrieved from http://repositori.usu.ac.id/handle/12345678 9/634

Gagola, L. S., Sondakh, J. J., \& Warongan, J. D. L. (2016). Analisis faktor-faktor yang mempengaruhi penyerapan anggaran pendapatan dan belanja daerah (apbd) pemerintah kabupaten kepulauan talaud, 108-117.

Ghozali, I. (2013). Aplikasi Multivariate dengan program SPSS (tujuh). Semarang: Badan Penerbit Universitas Diponegoro.

Halim, A., \& Kusufi, S. (2013). Akuntansi Sektor Publik, Akuntansi Keuangan Daerah. (Salemba empat, Ed.). Jakarta: Salemba Empat.

Halim, A., \& Kusufi, S. (2016). Teori, Konsep, dan Aplikasi Akuntansi Sektor Publik dari Anggaran hingga Laporan Keuangan, dari Pemerintah hingga Tempat Ibadah. (Salemba empat, Ed.) (2nd ed.). Jakarta: Salemba Empat.

Herriyanto, H. (2012a). Faktor-Faktor yang Mempengaruhi Ketelambatan Penyerapan Anggaran Belanja Pada Satuan Kerja Kementrian/Lembaga di Wilayah Jakarta. Universitas Indonesia.

Herriyanto, H. (2012b). Faktor-Faktor yang Mempengaruhi Keterlambatan Penyerapan Anggaran Belanja pada SKL di Wilayah Jakarta. universitas indonesia.

https://jdih.kemenkeu.go.id/fullText/2014/3 P

MK.05 2014Per.HTM. (2014). Peraturan Menteri Keuangan Republik Indonesia Nomor 3/PMK.05/2014 tentang Penempatan Uang Negara pada Bank Umum.

Ikhsan, A. (2012). Akuntansi Sumber Daya Manusia suatu tinjauan penilaian modal manusia, 230.

Instruksi Presiden Republik Indonesia Nomor 1 Tahun 2015 Tentang Percepatan Pelaksanaan Pengadaan Barang dan Jasa Pemerintah (2015).

International organization Standardization. (2016). Komitmen manajemen dalam ISO 9001:2015.

Juliani, D., \& Sholihin, M. (2014). Pengaruh Faktor-Faktor Kontekstual Terhadap Persepsian Penyerapan Anggaran Terkait Pengadaan Barang / Jasa, 11(2), 177-199.

Kirnanda, A. (2016). Faktor-Faktor yang Mempengaruhi Penyerapan Anggaran Satuan Kerja Perangkat Daerah di Kota Binjai dengan Perubahan Anggaran Sebagai Variabel Moderating. Universitas Sumatera Utara. Retrieved from http://repositori.usu.ac.id/handle/12345678 9/547 
Mardiasmo. (2009). Akuntansi Sektor Publik. (ANDI, Ed.). Yogyakarta: ANDI.

Merchant, kenneth A., \& Stede, van der. (2016). Sistem Pengendalian Manjemen (3rd ed.). Jakarta: Salemba Empat.

Muhlizi, A. F. (2017). Penataan regulasi dalam mendukung pembangunan ekonomi nasional. Rechts Vinding Media Pembinaan Hukum Nasional, 6, 349-368.

Rerung, E. D. (2016). Faktor-Faktor Yang Mempengaruhi Penyerapan Anggaran Belanja Pemerintah Daerah: Proses Pengadaan Barang / Jasa Di Kabupaten Bolaang Mongondow Selatan, 192-202.

Rifai, A. (2011). Analisis faktor-faktor yang mempengaruhi keterlambatan daya serap anggaran ( Studi Empiris Pada SKPD Pemprov NTB ), 1-10.

Sembiring, J. H. (2017). Faktor-Faktor Yang Mempengaruhi Keterlambatan Penyerapan Anggaran Belanja Direktorat Jenderal Pendidikan Anak Usia Dini Dan Pendidikan Masyarakat.

Sudastri, D. (2016). Pengaruh Perencanaan Anggaran dan Kompetensi Sumber Daya Manusia Terhadap Penyerapan Anggaran, $1-22$.

Sugiyono. (2014). Metode Penelitian Kuantitatif, Kualitatif, dan $R \& D$. (CV.ALFABETA, Ed.). Bandung:
CV.ALFABETA.

Suryani, \& Hendriyadi. (2015). Metode Riset Kuantitatif Teori dan Aplikasi pada penelitian bidang manajemen dan ekonomi islam. (Kencana, Ed.). Jakarta: kencana.

UU Nomor 12 tentang pembentukan peraturan perundang-undangan (2011).

UU RI No.43 tahun 1999 tentang Perubahan atas Undang-Undang Nomor 8 Tahun 1974 tentang Pokok-Pokok Kepegawaian (1999).

www:finance.detik.com/berita-ekonomibisnis/d-4119916/sri-mulyani-catatserapan-anggaran-kemenhub-dan-puprmasih-rendah. (2018). Sri Mulyani Catat Serapan Anggaran Kemenhub dan PUPR Masih Rendah.

www.djpk.kemenkeu.go.id. (n.d.). perencanaan dan penganggaran keuangan daerah.

www.monev.riau.go.id. (n.d.). APBD Dinas Pekerjaan Umum dan Perumahan Rakyat Provinsi Riau.

www.Tribunpekanbaru.com. (2018). enam proyek strategis Pemprov Riau disebut masih sesuai target.

Zarinah, M. (2016). pengaruh perencanaan anggaran dan kualitas sumber daya manusia terhadap tingkat penyerapan anggaran satuan kerja perangkat daerah di kabupaten Aceh Utara, 5(1), 90-97. 